\title{
Analysis the Fulfilment of Physical and Psychological Needs of Convicted Criminal From An Islamic Law Perspective
}

\author{
Safiuddin Sifiuddin ${ }^{1 *}$ Muhammad Akbar2, Muhammad Syarif Hasyim³, \\ ${ }^{1}$ Islamic Law Department, Postgraduate, Institut Agama Islam Negeri Palu \\ 2 Islamic Law Department, Postgraduate, Institut Agama Islam Negeri Palu \\ ${ }^{3}$ Faculty of Islamic Law, Institut Agama Islam Negeri Palu
}

\begin{tabular}{|c|c|}
\hline ABSTRACT & $\begin{array}{l}\text { ARTICLE } \\
\text { INFORMATION }\end{array}$ \\
\hline $\begin{array}{l}\text { This study discusses the implementation of conditional leave } \\
\text { (CL) in fulfilling prisoners' physical and phsychological need of } \\
\text { prisoners from Islamic law perspectives. This study used } \\
\text { qualitative method with data collection techniques through } \\
\text { observation, indepth-interviews and written material analysis. } \\
\text { Data was analysed through data reduction, presentation, } \\
\text { verification, and drawing conclusions. The results of the study } \\
\text { show that obligatory livelihoods for husbands with prisoner } \\
\text { status was fulfilled through the efforts made by inmates such } \\
\text { as a business that is still moving and producing that can be } \\
\text { used by the wife to meet needs. Less implemented, this is } \\
\text { based on the still potential of prisoners to provide for their } \\
\text { wives needs through the provision of relatives even though the } \\
\text { fulfillment of the quality of living needs is not optimal. While } \\
\text { the fulfillment of the psychological needs supported by } \\
\text { inmates, namely giving love, education, and distribution of } \\
\text { sexual desires, in the form of face-to-face and joking with his } \\
\text { wife, while channeling sexual desires in the effort to fulfill the } \\
\text { inner living is rarely done except for prisoners getting } \\
\text { conditional leave (CL) ). The livelihood of the husband who is } \\
\text { undergoing a period of punishment is not contrary to Islamic } \\
\text { law, although on one hand the status remains as a family head } \\
\text { who has obligations that must be fulfilled. Islam views this } \\
\text { with three legal stipulations, the first is the obligation to make } \\
\text { a living, the second is the obligation to earn a living and the } \\
\text { third is the obligation to make a living fall. }\end{array}$ & $\begin{array}{l}\text { Phisical needs, } \\
\text { spritual needs, } \\
\text { convicted criminal, jail }\end{array}$ \\
\hline
\end{tabular}




\section{International Journal of Contemporary Islamic Law and Society}

Vol. 2 No. 1 Tahun 2020

\section{Introduction}

In this globalized modern world today, all aspects of household needs increase, so that economic needs in the family will also continue to grow, and responsibility will be even greater in meeting daily needs. A husband is obliged to provide for his wife the maintenance physically and mentally for her daily needs. The provision of sustenance both physically and mentally in the family is very important in fostering and harmonizing the family, even after divorce, the provision of maintenance is still the responsibility of the husband.

To establish a harmonious household should involve all family members from husband, wife and children. They certainly have the duties and responsibilities in order to create a happy family. The husband has the duties and responsibilities as a leader and breadwinner for the family, while the wife as a companion to the husband as well as a mother in the household. If the marriage contract that occurred between husband and wife is valid, it will lead to the rights and obligations of husband and wife in the family. ${ }^{1}$

However, the issues related to the maintenance are frequently not in accordance with the implementation, due to certain conditions. One example is that one of them is in a Detention House (RUTAN), so the husband and wife must stay for some time to conduct investigations and trials. The harmony

${ }^{1}$ Abd. Rahman Ghazaly, Fiqih Munakahat (Jakarta: kencana,2006), 155. that is intertwined will be different from before, because the husband and wife do not live together but the bond of marriage is still intertwined.

Islam provides many rules for safeguarding marriage. One of them is fulfilling the rights and obligations of husband and wife in the marriage itself. The rights and obligations of husband and wife must be carried out and fulfilled by each party in order to create a family that remains intact and harmonious, so that they can work together in reaching a harmonious family. From this fact, it is clear that the rights and obligations of husband and wife as a consequence of the marriage is the fulfillment of physical and spiritual needs so that the couple is expected to be aware of the importance of carrying out their rights and obligations.

If maintenance is understood as living costs, then in terms of Islamic law, it is the right of the wife and children in terms of food, clothing and residence as well as several other basic needs and treatment, even if the wife is a rich woman. ${ }^{2}$ Islam has established the rule that the obligation of the husband is to provide physical and spiritual support to his wife. This includes providing food, drink, clothes, jewelry and so on, while the inner sustenance is the fulfillment of biological and psychological needs, such as love and affection, attention, protection, and so on.

2Slamet Abidin, Fiqih Munakahat 1 (Bandung: CV. Pustaka Setia), 9. 


\section{International Journal of Contemporary Islamic Law and Society Vol. 2 No. 1 Tahun 2020}

The provisions regarding the rights and obligations of a husband and wife in a household are intended so that couples can understand each other, and know about the authority of each. Both can find out which are the rights or obligations of the husband or wife. Because what becomes the rightof wife is the obligation of husband to fulfill it, and the husband's right is the wife's obligation to fulfill it. ${ }^{3}$ With the existence of husband and wife's obligation, it is clear that the relationship between the two, that is, both must complement each other in the household. The Law Number 1 of 1974 Article 34 paragraph (1) states that a husband is obliged to protect his wife and provide all the necessities of household life in accordance with his abilities. ${ }^{4}$

This article contains instructions to the husband regarding two things, namely to protect the wife physically, therefore the husband is designated as the head of the household, providing the necessities of life, that can be specified outwardly and inwardly, the husband must meet the needs of his wife in particular and the household in general.

But in reality, domestic life experiences various kinds of problems that cause a husband cannot give his obligations, such as the husband's status

3 Rusli, R. (2017). Wahdah Islamiyyah Palu: on Contemporary Islamic Legal Issues in The Internet. Hunafa: Jurnal Studia Islamika, 14(2)

4The Law Number 1 of 1974 Article 34 paragraph (1). as a prisoner in a detention center to serve his sentence. This makes all the prisoners' actions very limited. In these circumstances, as long as the wife is not incoherent and the husband does not divorce her, then the relationship between the two is still valid as husband and wife, which makes the husband still responsible for his wife. This is a problem faced by prisoners related to livelihood obligations.

The prisoners in Palu Detention Center have a variety of jobs before being detained in prison. From the data obtained, the work of the prisoners before serving a period of detention is a trader, and 5\% of detainees work as Civil Servants. ${ }^{5}$

This situation becomes worse when the husband bears the status of prisoner, while he is unable to carry out his responsibilities, then there is immediately a new burden that must be borne by the wife, namely maintaining the household in the condition of the husband who is undergoing a period of conviction, as well as she becomes the backbone of the family.

Luckily if the wife of the prisoner is a career woman who has income and is not too concerned about living for herself. However, for the wives whose economic life depends on their husbands, this condition will force them to work to fulfill their daily needs. And sometimes this becomes one of the reasons for ending his marriage, as regulated by the Government

5 Document of Detention Center, Class II A Palu 2019 


\section{International Journal of Contemporary Islamic Law and Society Vol. 2 No. 1 Tahun 2020}

Regulation No. 9/1975 Article 19 letter (c), which states that divorce can occur for the reasons that one of the parties received a 5 (five) year imprisonment or the hardest sentence after the marriage.

The issue of a husband's status as a convict and his obligation to provide for his family is an interesting issue to be studied more deeply. Therefore, the author is interested in conducting research on this issue.

\section{Literature Review}

2.1 The process of fostering prisoners in the Penitentiary System

The concept of correctionalism was first conceived by Minister of Justice Sahardjo in 1962, which stated that the duty of the prison department was not only carrying out the sentence, but returning people who were convicted of crime into society.

When a prisoner undergoes a sentence handed down by the court, then his rights as a citizen will be limited. Although the convicted person loses his or her independence, there are prisoners' rights that are still protected in the Indonesian correctional system. ${ }^{6}$

To carry out this coaching, there are four stages of the coaching process, namely:

The first stage. Every prison placed in the Correctional Institution is examined to find out his/her identity, including the reasons for their violations, and all information about

${ }^{6}$ Abdul Hakim G. Nusantara, Huki Acara Pidana (Jakarta: Sarwoko, 1986), 61-66. themselves that can be obtained from family, employers, colleagues, people who are victims of their actions, and agency officials who handled their case.

Second stage. If the process of fostering the prisoner has been going on for one third of his sentence, and in the opinion of the Society Observer Team (TPP), there has been quite progress, such as prisoner's remorse, improvement, discipline and compliance with the rules of order applicable in the Correctional Institution, then he is given more freedom by imposing a medium level of security supervision.

Third stage. If the guiding process for inmates has been going on for half of the actual criminal period, and according to the opinion of the Correctional Board of Adviser has been achieved progress physically, mentally, and skillfully, then the coaching process is expanded by allowing the prisoner to assimilate with the community outside Correctional Institution.

Fourth stage. If the process of fostering the prisoner has lasted for twothirds of the actual criminal period or at least nine months, the prisoner can be given conditional release, which the determination of the proposal is determined by the Correctional Board of Corrections. ${ }^{7}$

\subsection{Identification of Supporting Facilities and Infrastructure \\ In the process of fostering inmates} by the Penitentiary, supporting facilities

\footnotetext{
7http:/ /id.wikipedia.org/wiki/Lembag a_Pemasyarakatan, Diakses Maret 2019.
} 


\section{International Journal of Contemporary Islamic Law and Society Vol. 2 No. 1 Tahun 2020}

and infrastructure are needed in order achieve the desired success. Facilities and infrastructure include:

\section{a. Penitentiary Facility}

Penitentiary is a representation of the state of occupants in it. A proper building condition can support the fostering an expected process. In Indonesia itself, most of the penitentiary buildings are a colonial legacy, with infrastructure conditions that seem "haunted" and harsh. The high wall that surrounds it with iron trellis adds to the spooky impression of its inhabitants.

\section{b. Couching Prisoners}

Facilities for skills education in detention centers/prisons are very limited, both in number and type, and there are even facilities that are so old that they do not function anymore, or if they function, the results are inadequate with goods produced outside (company production.

\section{c. Officer in Detention Center}

Correctional officers are civil servants who handle the training of prisoners and detainees in detention centers. Regarding this matter, it can be said that it has not been fully able to support the achievement of the objectives of the coaching itself, bearing in mind that most of them are relatively not supported by provision of skills in conducting coaching with a humanist approach that can touch the feelings of prisoners, and is creative in coaching. ${ }^{8}$

\subsection{Paradigm System of Couching Prisoners}

Ironically, almost all of the crimes handled by the Indonesian Criminal Justice System always end up in prison. Even though prison is not the best solution in solving crime problems, especially crime where the "damage" caused by the crime can still be restored so that conditions that have been "damaged" can be returned to its original state, where in this restorative justice, it is possible to remove the stigma from individual offenders.

In a response to crimes deemed to be restored, there is a punishment paradigm known as restorative justice, in which perpetrators are encouraged to repair the harm that has been caused to the victims, their families and also the community. In connection with crimes whose damage can still be repaired, basically the public wants the perpetrators to be given rehabilitative services. The community hopes that the perpetrators of crime will be better than before they entered the prison. This is what is called the rehabilitation process. ${ }^{9}$

The needs and safety of victims are the main concerns of the restorative justice process. Victims must be supported and can be directly involved in the process of determining the needs of the final outcome of a criminal case they experienced. However, this does not mean that the needs of criminal offenders are ignored.

\footnotetext{
${ }^{9}$ http://id.wikipedia.org/wiki/Lembaga_Pema syarakatan, Diakses Maret 2019
} 


\section{International Journal of Contemporary Islamic Law and Society}

Vol. 2 No. 1 Tahun 2020

Perpetrators of crime must be rehabilitated and reintegrated into the community. As a consequence, it is necessary to exchange information between the victim and the perpetrators directly, and do a mutually beneficial agreement between the two as the final result of the criminal act.

\subsection{The Rights and Obligations of the} Prisoners

Based on Kamus Besar Bahasa Indonesia, a prisoner is a person who is serving a sentence for a crime. ${ }^{10}$ In legal terminology, a prisoner is a person who is a criminal living in a correctional institution. Based on Article 1 paragraph (7) of Law Number 12 Year 1995 concerning Penitentiary, prisoners are convicts who did the crime, missing independence at the Correctional Institution. According to Article 1 paragraph (6) of Law Number 12 Year 1995 concerning Corrections, a convicted person is a person who is convicted based on a court decision that has obtained permanent legal force. ${ }^{11}$

From the statement above, it can be concluded that the prisoner is a convict who is serving his sentence in prison, whose independence is lost.

The concept of human rights has two basic meanings; first, rights cannot be separated and revoked. These rights are moral rights derived from the humanity of every human being and those rights aim to guarantee the dignity

10 https://id.wikipedia.org/wiki/Narapidana, Accessed 20 March 2019.

11 The Law Number 12 of the Year 1995 on Penitentiary, Article 7. of every human being. Second, rights according to law, which are made in accordance with the legal process of the community itself, both nationally and internationally. The basis of these rights is the agreement of the citizens, who are subject to these rights.

In the Law Number 12 of 1995 Concerning Corrections, Article 14 stipulates that prisoners have the right:

a. Performing worship in accordance with their religion or beliefs;

b. Obtaining spiritual and physical care;

c. Getting education and teaching;

d. Obtaining proper health and food services;

e. Making a complaint;

f. Getting reading material and following other mass media broadcasts that are not prohibited;

g. Receiving a wage or premium for the work done;

h. Getting family visits, legal counsel, or certain other people;

i. Obtaining a reduced sentence (remission);

j. Getting opportunities to assimilate, including leave to visit family;

k. Getting parole;

1. Getting free leave; and

$\mathrm{m}$. Obtaining other rights in accordance with applicable laws and regulations. ${ }^{12}$

Human awareness of human rights stems from an awareness of the value of self-respect, dignity and human

${ }^{12}$ The Law Number 12 of the Year 1995 on Penitentiary Article 14. 


\section{International Journal of Contemporary Islamic Law and Society Vol. 2 No. 1 Tahun 2020}

dignity. ${ }^{13}$ Indeed, human rights have existed since humans were born in this world. Thus, human rights are not new. The Government of Indonesia, which respects and recognizes human rights, is committed to the protection of human rights at the implementation of the decision. ${ }^{14}, 15$ The commitment includes an institution of supervising judges, as regulated in Article 277 to Article 283 of the Criminal Procedure Code, and enactment of Law Number 12 of 1995 concerning Corrections, which emphasizes the activities of fostering prisoners based on institutional systems.

At the stage of the implementation of decision, human rights which are transformed into prisoners' rights are guaranteed and protected by law which means respect for human dignity. Article 10 of the ICCPR affirms that all persons who lose their freedom are treated with respect. The prison system must be based on the treatment of prisoners whose essence is social reform and rehabilitation. Underage offenders must be separated from adults and

${ }^{13}$ Iqbal, M., Rusli, R., \& Musyahidah, M. (2019). Management Strategies of

Professional Zakat Funds for Mustahiq Family Welfare By Amil Zakat Body. INTERNATIONAL JOURNAL OF CONTEMPORARY ISLAMIC LAW AND SOCIETY, 1(1), 39-51.

${ }^{14}$ Rusli, R. (2009). Gagasan Khaled Abu Fadl tentang "Islam Moderat" versus "Islam Puritan" (Perspektif Sosiologi Pengetahuan). Jurnal Ilmiah Ilmu Ushuluddin, 8(1), 99-123.

${ }^{15}$ Rusli, R. (2018). Fikih Ekologi dan Kearifan Tradisional: Tinjauan Terhadap Konsep Ihya' al-Mawat dan Hima. Hunafa: Jurnal Studia Islamika, 5(3), 287-298. given appropriate treatment for their business and legal status.

The prisoners' obligations based on Law No.12 of 1995 concerning correcting Article (15), stipulates: 1. Prisoners are required to follow in an orderly manner the training program and certain activities; 2. Provisions regarding the training program as referred to in paragraph (1) are further regulated by government regulations.

In detention centers, the prisoners' obligations include: 1) obeying all regulations in detention centre; 2) being polite, obedient and respectful to all officers; 3) respect to all fostered citizens; 4) maintaining security, order, cleanliness and beauty; 5) being neatly dressed and polite; 6) following the coaching program; 7) preserving state property; 8) depositing valuables; 9) notifying officers when seeing or knowing signs or conditions of danger for the security of prison. Rights and obligations are a benchmark for the success or failure of the coaching patterns carried out by officers to prisoners..$^{16}$

In this case, it can be seen whether or not the officers really pay attention to the rights of prisoners, and whether or not prisoners are aware of their rights, and obligations that must be carried out well. In this case, good cooperation between officers and prisoners is demanded.

\section{Methodology}

16 Regulations of rights and obligations of Detention Centre, Class II A Palu. 
This study used a qualitative approach with the object of research is prisoners in Palu Detention House. Data were obtained through observation, indepth interviews with the officials of the detention house and also several prisoners. While the data analysis is done using reduction and verification techniques with various data sources ${ }^{17}, 18$. The reduced data is then analyzed by referring to the theoretical concepts used in this study. ${ }^{19}$

\section{Result and Discussion}

\subsection{Forms of Fulfillment of Maintenance}

A married man is required to fulfill his obligations to his wife both physically and mentally, specifically the husband's obligations related to food, clothing, shelter, the costs of household and care, and medical expenses, until there is a stipulation that the husband is no longer required to carry out his obligations. In this case, a husband who is a prisoner, has various obstacles in providing sustenance to his wife and

17 Nurdin, N. (2017a). Research in Online Space: The Use of Social Media for Research Setting Jurnal Sistem Informasi (Journal of Information System), 13(1), 67-77.

18 Nurdin, N. (2017b). To Research Online or Not to Research Online: Using Internet-Based Research in Islamic Studies Context. Indonesian Journal of Islam and Muslim Societies, 7(1), 31-54.

19 Nurdin, N. (2016). The Roles of Information Technology in Islamic Bank Knowledge Management: A study of Two Syariah Banks in Palu. Hunafa: Jurnal Studia Islamika, 13(2),

181-217. https://doi.org/https://doi.org/10.24239/jsi.v1 3i2.444.181-217 family, because of the limitations possessed by a prisoner in which he loses his independence.

Based on the interview, the implementation of prisoners' obligations to provide sustenance to their wives is relative. Some are able to provide a living, and others are not. The implementation of the living can be categorized into three:

\section{a. Being Implemented}

Even though the husband is a prisoner, he can still provide sustenance for his wife. One of the implementations is the husband gives authority to manage his business to his family who was left behind to meet family needs. As a prisoner (AM) said:

I traded satay with my wife, before being here in this detention center, and now the business is continued by my wife and parents-in-law. Before here, I also managed our own rice fields and gardens, and now also my wife continues it. ${ }^{20}$

Fulfillment of livelihood obligations given by the husband to the wife is indeed not as maximal as when the husband has not served the sentence. However, by delegating the right to his wife to continue businesses, the husband's livelihood obligations are fulfilled indirectly. The wife feels no objection to continuing the business to meet daily needs. This was said by the prisoner's wife (Ms. Neldawita, 33 Years):

\footnotetext{
${ }^{20}$ Interview with AM in Detention House Class II A Palu (15 July 2019).
} 
The result is, alhamdulillah, adequate, and sometimes my husband gets a shipment from his parents when visiting him, and gives it to me and my child a little for spending money. Alhamdulillah, I am grateful, even though with such a condition he still remembers his responsibility towards us, even though I am sincere with his condition as a husband who did not deliver the shipment to us, because I know the cost of living inside is far greater than outside. ${ }^{21}$

\section{b. Impartially Implemented}

As revealed by one of the prisoners (MA):

My presence here makes me unable to provide for my living to my family as I usually do, when I became an honorary teacher. Therefore, my wife chose to live in her parents' house. But now in terms of providing family income, I only get help from my parents and close relatives through money transferred to me. So when there is a shipment that I considered quite large, I give it to my wife. ${ }^{22}$

From this information, it can be said that the liability is still fulfilled but in an inadequate manner. The same also applies to other prisoners (informants), such as $\mathrm{OH}$ and $\mathrm{MR}^{23}$

21 Interview with Neldawita, a prisoner's wife (17 July 2019).

22 Interview with MA, a prisoner in Detention House Class II Palu (26 July 2019).

23Interview with $\mathrm{OH}, \mathrm{MR}$, prisoners of Detention House Class II Palu (29 July 2019). who also got shipment from their relatives, and gave to their wives when visiting them.

\section{c. Not Well Implemented}

This is the third category that is found in this Detention House, that providing sustenance to the wife is not implemented well. As ZBH, a prisoner, said,

Regarding the provision of livelihoods that have become my obligation, I feel I do not do my task well as a husband, who should provide maintenance for his wife and children. In the past, I am a civil servant, and my salary was fully managed by the wife to meet daily needs, but now it is reversed, the wife who supports the children, even meets my needs while undergoing a sentence in this detention center. My wife became a civil servant teacher at the residence Within a week, 2 to 3 times my wife visited me bringing food and giving money for my needs inside. ${ }^{24}$

A similar situation happened to other informant who also works as a civil servant undergoing prison sentences, and his wife is also a civil servant. With a fixed income received by the wife, all forms of husband's needs in detention can be fulfilled. As she said,

Alhamdulillah, I still have a regular income every month with various

${ }^{24}$ Interview with $\mathrm{ZBH}$, a prisoner of Detention House Class II Palu (31 July 2019). 
allowances. So, I can meet the needs of my life, children and all my husband' needs in prison. ${ }^{25}$

\subsection{The Way of Fulfilling Inner Sustenance}

a. Communication via SMS and Cellurlar Phone with Family

Efforts to fulfill inner living can include biological and psychological needs. A form of inner living that is often done by prisoners is psychological inner sustenance, by sending SMS, calling family, and joking while wives are visiting them.

A form of fulfillment of inner living through SMS and family calls are often carried out by prisoners when the feeling of longing arises even if it is only to find out the condition and news of his wife and family, as expressed by a prisoner (RR) in an interview. ${ }^{26}$

However, the fulfillment of the inner needs through sending SMS or calling family is considered less effective. Because there is a regulation in Detention Center Class II Palu, that the prisoners are not allowed to bring, use, or borrow cellphones to the officers. So, in order to send SMS or call a family, prisoners are forced to do that clandestinely, because, if they are caught of carrying, using, or borrowing a cellphone, the consequence is that the prisoner's cellphone is confiscated and will not be returned until they are released from detention or prisons.

${ }^{25}$ Interview with Putri Andini, a wife of prisoner (1 August 2019).

26 Interview with RR, a prisoner in Detention House, Class II Palu (5 August 2019).
Although there are communication tools provided by the household but it is limited only to important matters.

\section{b. Face-to-face Meeting}

Another form of inner sustenance is a face-to-face encounter at the visit. Family visit is highly expected by prisoners, because with these visits prisoners can get out temporarily from prison, just to breathe fresh air with a new atmosphere that can refresh the body and mind, compared to being trapped in a cell room crowded with humans and cigarette smoke. In addition, this made it easy for them to express their longing and communicate between families. As a prisoner (AM) said,

Fulfillment of inner living that I can do it does not have to be in the form of having sexual intercourse. My wife who came to visit me, even though only to chat face to face, was able to meet the inner maintenance. ${ }^{27}$

In contrast to the opinion of the six respondents who said that the fulfillment of the inner sustenance is related to a biological inner living in the form of having sexual intercourse because, in their view, this will affect the creation of harmony even though the facilities are inadequate or even not available.

\section{c. Granting Conditional Leave}

27 Interview with $\mathrm{AM}$, a prisoner in Detention House, Class II Palu (7 August 2019). 
Inner sustenance can be obtained when the prisoners get conditional leave. Giving conditional leave is based on the principle of justice which is the legal basis of various legislation in Indonesia. The Law 12 of Year 1995 on Corrections, for example, lists various rights that can be obtained by the prisoners while in detention. However, not all conditional leave can be granted. This condition is stipulated in the Minster of Law and Human Rights Regulation, Number 03 Year 2018 regarding the Requirements and Procedures for Granting Remission, Assimilation, Family Visit Leave, Conditional Release, Leave Towards Free.

With this conditional leave, the prisoners can fulfill inner sustenance for their wives. They also can communicate with the public, while stay in control of the officers from the Center of Correction (BAPAS) during the period of conditional leave.

Fulfillment of inner living that can be carried out in the prison is related to psychological and biological aspect, so sending SMS, family visits, and family call is sufficient, even the fulfillment of the inner living that is related to biological aspect, such as sexual intercourse, is often done during his wife's visit. This has an influence on family harmony, especially families left by their husbands/parents in prison. However, based on the interview, those who get paid leave have been able to fulfill their physical and spiritual needs, but that does not apply to all prisoners, but can only be done for the prisoners based on the rules as explained before.

\section{Conclusion}

From the above discussion, it can be concluded that the fulfillment of inner sustenance in the Detention Centre Class II A Palu can be categorized into three: implemented, partially implemented, and not well implemented.

Providing inner living in this Detention Centre includes affection, love, and sexual intercourse, in the form of face-to-face encounter of the prisoner to his wife, while sexual relations are rarely carried out by the prisoners, in order to keep his wife's honor before the public, except for prisoners who get leave

\section{REFERENCES}

Abidin, Slamet. Fiqih Munakahat I. Bandung : CV. Pustaka Setia, 2013.

Alex, Sobur. Psikologi Umum. Bandung : CV. Pustaka Setia, 2003.

A l-Hafid, Ibnu. Bidayat al-Mujtahid wa Nihayat al-Muqtashid. Surabaya: Al- Hidayah, 1999.

Al-Qurthubi, Muhammad. Al-Jami' li Ahkam Al-Quran Juz XVIII. Beirut: Dar-al- Ihya li Tirkah al-Arabi, 1985.

Amini, Ibrahim. Bimbingan Islam Untuk Suami isteri. Bandung, AlBayan, 2000.

Amir, Syarifuddin. Hukum Perkawinan di Indonesia: antara Fiqih Munakahat dan Undang- 
Undang Perkawinan. Jakarta: Kencana, 2006.

Basri, Hasan. Keluarga Sakinah. Yogyakarta: Pustaka Pelajar 1995.

Bungin, Burhan. Peneiltan Kualitatif, Komunikasi, Ekonomi, Kebijakan Publik, dan Ilmu Sosial lainnya. Cet. I; Jakarta: Kencana Prenada Media Group, 2007.

Burhanuddin, Afid.

https://wordpress.com/2013/0 5/21/landasan-teori-kerangkapikir-dan-hipotesis/,

Diakses 20 Maret 2019

Departemen Agama RI. KHI dan UU.1 thn 1974 Tentang Perkawinan. Jakarta: 1996.

Departemen Agama RI. Al-Qur'an dan terjemahnya. Bandung: Mizan, 2009.

Departemen Pendidikan dan Kebudayaan RI. Kamus Besar Bahasa Indonesia Edisi II. Jakarta: Balai Pustaka, 1996.

Departemen Pendidikan Nasional. Kamus Besar Bahasa Indonesia. Cet. II; Jakarta: Balai Pustaka, 2005.

Ezmir. Metodologi Penelitian Kualitatif Analisis Data, Cet.II. Jakarta: PT. Raja Grafindo Persada, 2011.

Ghazaly, Abd. Rahman. Fiqih Munakahat. Jakarta: kencana, 2006.

Hakim, Rahmat. Hukum Pernikahan Islam. Bandung: Pustaka Setia, 2000.

Hasan, M. Ali. Pedoman Berumah Tangga dalam Islam. Jakarta: Siraja, 2006.

Hasby As-Syiddiqi, Muhammad. Hukum-Hukum Fiqih Islam:
Tinjauan Akhir Antar

Madzhab. Semarang : Pustaka Riski Putra, 2001.

http:/ / blogpengertian.com/arti -implementasiPengertian Implementasi Menurut

Para Ahli, Diakses 20 Maret 2019.

Imron, Arifin. Penelitian Kualitatif dalam Ilmu-ilmu Sosial dan Keagamaan, Cet. III. Malang: Kalimasada Press, 1996.

Ishaq Ibrahim bin Ali bin Yusuf, Imam Abu . Kunci Figh Syafi"i, Terj. Hafid Abdullah. Semarang : AsySyifa"', 1992.

Iqbal, M., Rusli, R., \& Musyahidah, M. (2019). Management Strategies of Professional Zakat Funds for Mustahiq Family Welfare By Amil Zakat Body. INTERNATIONAL JOURNAL OF CONTEMPORARY ISLAMIC LAW AND SOCIETY, 1(1), 39-51.

Margono, S. Metode Penelitian

Pendidikan. Cet. II; Jakarta: Rineka Cipta, 2000.

Mazhari, Husain. Membangun Surga Dalam Rumah Tangga. Bogor: Cahaya, 2004.

Milles, Metthew B. dan Hubarman, A. Michael. Qualitative Data Analisis, diterjemahkan oleh Tjecep Rohendi, Analisis Data Kualitatif. Buku Tentang Metode-metode Baru. Cet. I; Jakrta: UI Press, 2005. 
Moleong, Lexy J. Metodologi Penelitian Kualitatif. Cet. XIV; Bandung: Remaja Rosda Karya, 2001.

Mudhlur, Zuhdi A. Hukum Perkawinan. Cet ke 1, Jakarta: Al-Bayan, 2001. Mughniyah, Muhammad Jawad. Fiqih Lima Maddzhab Ja"fari, Hanafi, Maliki, Safi"i, Hambali. Jakarta: Lentera, Cetakan 25, 2010.

Munawir, Ahmad Warson. Kamus Al Munawwir. Yogyakarta: Gema Press, 1984.

Muthahari, Murtadha. Hak-Hak Wanita Dalam Islam, Terj. Muhammad Anshorie. Jakarta: Lentera, 2000.

Nasution, Khoiruddin. Hukum Perkawinan I. Yogyakarta: ACAdemia, 2013.

Nurdin, N. (2016). The Roles of Information Technology in Islamic Bank Knowledge Management: A study of Two Syariah Banks in Palu. Hunafa: Jurnal Studia Islamika, 13(2), 181217.

https:/ / doi.org/https:/ / doi.org/ 10.24239/jsi.v13i2.444.181-217

Nurdin, N. (2017a). Research in Online Space: The Use of Social Media for Research Setting Jurnal Sistem Informasi (Journal of Information System), 13(1), 67-77.

Nurdin, N. (2017b). To Research Online or Not to Research Online: Using Internet-Based Research in Islamic Studies Context. Indonesian Journal of Islam and Muslim Societies, 7(1), 31-54.
Peraturan Menteri Hukum Dan Hak Asasi Manusia Republik Indonesia Nomor 03 Tahun 2018 Tentang Syarat Dan Tata Cara Pemberian Remisi, Asimilasi, Cuti Mengunjungi Keluarga, Pembebasan Bersyarat, Cuti Menjelang Bebas, Dan Cuti Bersyarat

Rahmat, Aibdi. Pemikiran Fiqih Al-Sayyid Sabiq Dalam Bidang Ibadah, MIQOT Vol. XXXIII No. 1 Januari-Juni 2009, 8.

Robert C. \& Stren J. Tailor. Kualitatif, Dasar-Dasar Penelitian. Usaha Nasional, 1993.

Rusdy, Ibnu. Bidayatul Mutahid, jilid. I, terj Harsi Abdullah dan Abdurrahman. Semarang: AsySyifa, 1990.

Ruslan, Rosady. Metode Penelitian Public Relation dan Komunikasi. Cet. IV; Jakarta: PT. Raja Grafindo Persada, 2004.

Rusli, R. (2009). Gagasan Khaled Abu Fadl tentang "Islam Moderat" versus "Islam Puritan" (Perspektif Sosiologi Pengetahuan). Jurnal Ilmiah Ilmu Ushuluddin, 8(1), 99123.

Rusli, R. (2018). Fikih Ekologi dan Kearifan Tradisional: Tinjauan Terhadap Konsep Ihya' al-Mawat dan Hima. Hunafa: Jurnal Studia Islamika, 5(3), 287-298.

Rusli, R. (2017). Wahdah Islamiyyah Palu: on Contemporary Islamic Legal Issues in The Internet. Hunafa: Jurnal Studia Islamika, 14(2) 
Rusyd, Ibnu. Bidayah al-Mujtahid, Penerjemah; M.A. Abdurrahman. Semarang: AsySyifa', 1990.

Sabiq, Sayyid. Fikih Sunnah 7, Terj. Muhammad Thalib. Bandung: al-Ma"arif, 1987.

Sabiq, Sayyid. Fiqih Sunnah, terjemah. Nor Hasanuddin dkk. Jakarta : Pena Pundi Aksara, 2007.

Sarlito W. Sarwono. Berkenalan Dengan Aliran-Aliran dan Tokoh-tokoh Psikologi. Jakarta : PT. Bulan Bintang, 2000.

Sarwono, Sarlito Wirawan. Menuju Keluarga Bahagia 2. Jakarta: Bhatara Karya Aksara, 1982.

Shihab, Quraish. Tafsir Al-Misbah. Jakarta: Lentera, 2000.

Subianto, Paulus. Membahagiakan Pasangan. Jakarta PT.Gramedia Utama 2004

Sudirman, Rahmat. Konstruksi Seksualitas Islam. Yogyakarta : Media Pres.,sindo,1999.

Sugiyono. Metode Penelitian Kuantitatif, Kualitatif dan $R$ \& $D$. Cet.VI; Bandung: Alfabeta, 2009.

Suhartono, Irawan. Metode Penelitian Sosial. Cet. V; Bandung: Remaja Rosdakarya, 2002.

Surakhmad, Winarno. Dasar dan Teknik Research. Pengentar Metodologi Ilmiah. Bandung: Torsito, 1978.

Syukur, Abdul. Ensiklopedi Umum Untuk Pelajar. Jakarta : Ichtiar Baru van Hoeve, 2005.

Tholib, Muhammad. Perkawinan Menurut Islam. Surabaya: AlIkhlas, 1993.
Umar, Husein. Metode Penelitian untuk Skripsi dan Tasir Bisnis. Cet. IV ; Jakarta: PT. Raja Grafindo, 2000. Undang-Undang No.12 tahun 1995 tentang pemasyarakatan Pasal 3 Yin, Robert K. Case Study Design and Methods, diterjemahkan oleh M. Djauzi Mudzakir dengan judul: Studi Kasus Desain dan Metode, Cet.I Jakarta: PT.Raja Grafindo Persada, 2002 